\title{
CLINICAL PROFILE OF PATIENTS WITH INFLUENZA LIKE ILLNESS
}

\author{
Lydia Solomon ${ }^{1}$, Mary John², John Livingston ${ }^{3}$
}

${ }_{1}^{1}$ Assistant Professor, Department of Medicine, Christian Medical College and Hospital, Ludhiana, Punjab, India.

2Professor, Department of Medicine, Christian Medical College and Hospital, Ludhiana, Punjab, India.

${ }^{3}$ Senior Resident, Department of Cardiology, Christian Medical College and Hospital, Ludhiana, Punjab, India.

\section{ABSTRACT}

\section{BACKGROUND}

Respiratory infections caused by seasonal influenza is associated with significant morbidity and mortality. The objective of our study was to analyse the clinical profile, complications and outcome of patients admitted with Influenza like illness during the epidemic of H1N1.

\section{MATERIALS AND METHODS}

Patients admitted with a diagnosis of suspected H1N1 were included in the study. Test for H1N1 by PCR was done only in WHO category $\mathrm{C}$ cases. Others were diagnosed on the basis of clinical criteria. Based on the results, patients were divided into 3 groups, H1N1 positive (Group 1), H1N1 negative (Group 2) and H1N1 untested group (Group 3). The 3 groups were compared and analysed based on their clinical profile, laboratory investigations, complications and their outcome.

\section{RESULTS}

A total of 155 patients formed our study group. All belonged to category $\mathrm{C}$ and were treated with Oseltamivir. 87 patients could be tested for H1N1, 38 of whom were positive. Based on test results, the patients were divided into 3 groups, namely group 1 (tested positive), group 2 (tested negative) and group 3 (Could not be tested). There were females more than males in all 3 groups (87 and 68 respectively). Majority, 74 (47.7\%) of patients were between $40-59$ years of age. Most of the patients $96(61.9 \%)$ presented within 7 days of illness. Diabetes mellitus was the most common co morbidity observed in 63 patients (40.6\%) and 16 (10.3\%) patients had an underlying lung disease. 8 (5.2\%) were on steroids. Fever and cough were the first noticed symptoms in 75 (48.4\%) and 45 (29\%) patients respectively. Nasal catarrh and sore throat were seen as the first symptom only in 15 (9.7\%) and $5(3.2 \%)$ patients respectively. Moderate ARDS was seen in 91 (58.7\%) patients and severe ARDS was seen in 22 (14.2\%) patients. $26(68.4 \%)$ patients in group 1 required mechanical ventilation compared to group 2, and group 3 i.e. 17 (34.7\%) and 10 (14.7\%) respectively. 22 (44.9\%) patients in group 2 could be managed on non-invasive ventilation. Other complications noticed were Cardiovascular in $18(11.6 \%)$ patients, (STEMI, NSTEMI, Myocarditis, Atrial fibrillation), Acute Kidney Injury in 18 (11.6\%) and neurological in 8 (5.2\%) Critical illness neuropathy, dysautonomia, infarcts (Pontine, multicerebral), polyneuropathy, intracerebral haemorrhage. There was a total of $56(36.1 \%)$ deaths, majority of them, 30 (53.6\%) had moderate ARDS. There was $100 \%$ mortality in patients with severe ARDS in group 1. 55 patients (35.4\%) had AKI, out of which $63.6 \%$ expired. Patients who presented with hypotension, 8 (66.6\%) also had high mortality rate.

\section{CONCLUSION}

Severe ARDS at presentation could be used as a predictor for mortality. However, despite the early presentation, severity of the disease was unaltered.

\section{KEYWORDS}

Influenza; Clinical Profile: Varied Complications.

HOW TO CITE THIS ARTICLE: Solomon L, John M, Livingston J. Clinical profile of patients with influenza like illness. J. Evolution Med. Dent. Sci. 2019;8(06):352-354, DOI: 10.14260/jemds/2019/77

\section{BACKGROUND}

Emergence of Flu like illness in the beginning of the year 2015 , posed a major threat all over the country. It caused significant mortality and morbidity. As this virus is highly transmissible and was rapidly spreading from one person to the other and from one place to the other, the health care system workers had to take immediate action in isolating and managing the affected patients.

'Financial or Other Competing Interest': None.

Submission 07-11-2018, Peer Review 19-01-2019,

Acceptance 04-02-2019, Published 11-02-2019.

Corresponding Author:

Lydia Solomon,

Department of Medicine,

Christian Medical College and Hospital,

Brown Road, Ludhiana-141008, Punjab, India.

E-mail: lydiasolomon777@gmail.com

DOI: $10.14260 /$ jemds $/ 2019 / 77$
There were different opinions on the severity of the infection by various groups. (1-5) Knowing the severity of the disease will be of immense help not only to treat the present cases but also in preventing a major pandemic in the coming years.

H1N1 caused many deaths and was seen as a pandemic for the first time in Spain in 1918. Later many outbreaks were noted, the last one being in 2009. In April 2009, the first case of Influenza A H1N1 was reported in Mexico.(6) During the same pandemic, the first case in India was reported in

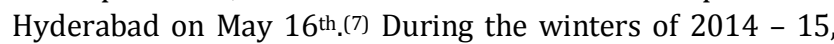
there was a spurt of influenza cases.

In our tertiary care center, there was a rise in the number of patients from January to March 2015. The patients presented with various degrees of severity and had a varied presentation. This study was done to study the clinical profile, the severity of the disease and the outcome of the patients who were admitted with flu like illness in the 
winters of 2014-2015. The aim of our study was to analyse the clinical profile, complications and outcomes of patients admitted with signs and symptoms of Influenza from January to March 2015.

\section{MATERIALS AND METHODS}

The following study was an observational study at Christian Medical College and Hospital, Ludhiana. All the patients admitted with a diagnosis of suspected H1N1, belonging to category $\mathrm{C}$ were included in the study. Test for H1N1 by PCR was done. Based on the results, patients were divided into 3 groups, H1N1 confirmed positive cases (Group 1), H1N1 tested negative patients (Group 2) and H1N1 untested group (Group 3).

A total of 155 patients formed our study group. 87 patients could be tested for H1N1, 38 of whom were positive (Group 1), 49 were negative (Group 2) and 68 could not be tested (Group 3). The clinical profile, laboratory parameters, complications and outcome among the various groups were compared and analysed.

\section{Statistical Analysis}

In the descriptive analysis, continuous variables were expressed as Mean \pm S.D and categorical variables were expressed as count (percentage). Chi-square was used to compare the categorical variables between the groups. The significance level was set at $\mathrm{p}<0.05$. All statistical analysis was performed using SPSS, version 21.0. Armonk, NY: IBM corp.

\section{RESULTS}

A total of 155 patients formed our study group. All belonged to category $\mathrm{C}$ and were treated with Oseltamivir. 87 patients could be tested for H1N1, 38 of whom were positive. Based on test results, the patients were divided into 3 groups, namely group 1 (Tested positive), group 2 (Tested negative) and group 3 (Could not be tested).

Among the 155 patients, 53 (34.1\%) had no comorbidities. Diabetes mellitus was the most common co morbidity seen among the patients. $10.3 \%$ (16/155) of the patients had underlying chronic lung disease.

Male: Female ratio was 1:1.2

Women were more in number in all the groups. Middle aged group (40 to 59 years) were affected more. (Table 1)

\begin{tabular}{|c|c|c|c|c|c|c|c|}
\hline & $\begin{array}{c}\text { Group 1 } \\
(\mathbf{n = 3 8 )}\end{array}$ & $\mathbf{\%}$ & $\begin{array}{c}\text { Group 2 } \\
(\mathbf{n = 4 9})\end{array}$ & $\mathbf{\%}$ & $\begin{array}{c}\text { Group 3 } \\
(\mathbf{n = 6 8})\end{array}$ & $\mathbf{\%}$ & $\mathbf{p}$-Value \\
\hline Male & 17 & 44.7 & 18 & 36.7 & 33 & 48.5 & 0.445 \\
\hline Female & 21 & 55.3 & 31 & 63.3 & 35 & 51.5 & \\
\hline $\begin{array}{c}\text { Age } \\
20-39\end{array}$ & 9 & 23.7 & 13 & 26.5 & 21 & 30.9 & 0.406 \\
\hline $40-59$ & 23 & 60.5 & 23 & 46.9 & 28 & 41.2 & \\
\hline$>60$ & 6 & 15.8 & 13 & 26.5 & 19 & 27.9 & \\
\hline \multicolumn{7}{|c|}{ Table 1 } \\
\hline
\end{tabular}

Most of the patients presented within 7 days of illness.

Fever, cough and breathlessness were the most common symptoms during presentation. Nasal catarrh and sore throat were seen only in $34.8 \%$ (54/155) of the patients.

Patients who were tested positive had a higher level of transaminases and thrombocytopenia when compared to the tested negative patients. (Table 2)

\begin{tabular}{|c|c|c|c|c|c|c|c|}
\hline & $\begin{array}{c}\text { Group 1 } \\
(\mathbf{n = 3 8})\end{array}$ & $\%$ & $\begin{array}{c}\text { Group 2 } \\
(\mathbf{n = 4 9 )}\end{array}$ & $\mathbf{\%}$ & $\begin{array}{c}\text { Group 3 } \\
(\mathbf{n = 6 8})\end{array}$ & \% & $\begin{array}{c}\text { p- } \\
\text { Value }\end{array}$ \\
\hline $\begin{array}{c}\text { Low } \\
\text { Platelets }\end{array}$ & 20 & 52.6 & 13 & 26.5 & 20 & 29.4 & 0.021 \\
\hline $\begin{array}{c}\text { High } \\
\text { SGOT }\end{array}$ & 32 & 84.2 & 23 & 46.9 & 34 & 50 & 0.001 \\
\hline $\begin{array}{c}\text { High } \\
\text { SGPT }\end{array}$ & 23 & 60.5 & 17 & 34.7 & 29 & 42.6 & 0.051 \\
\hline \multicolumn{7}{|c|}{ Table 2 } \\
\hline
\end{tabular}

The $\mathrm{P} / \mathrm{F}$ ratio was $<200$ in majority of the patients, representing that majority of patients had moderate to severe ARDS at presentation. (Table 3)

\begin{tabular}{|c|c|c|c|c|c|c|c|}
\hline $\begin{array}{c}\mathrm{Pa02} / \mathrm{FiO2} \\
\text { ratio }\end{array}$ & \begin{tabular}{|c|} 
Group 1 \\
$(\mathrm{n}=38)$
\end{tabular} & $\%$ & \begin{tabular}{|c|} 
Group 2 \\
$(\mathrm{n}=49)$
\end{tabular} & $\%$ & $\begin{array}{c}\text { Group 3 } \\
(\mathrm{n}=68)\end{array}$ & $\%$ & $\begin{array}{c}\text { p- } \\
\text { Value }\end{array}$ \\
\hline $\begin{array}{l}0-100 \\
\text { Severe }\end{array}$ & 8 & 21.1 & 8 & 16.3 & 6 & 8.8 & 0.028 \\
\hline $\begin{array}{c}100-200 \\
\text { Mod Severe }\end{array}$ & 26 & 68.4 & 29 & 59.2 & 36 & 52.9 & \\
\hline$>200$ & 4 & 10.5 & 12 & 24.5 & 26 & 38.2 & \\
\hline
\end{tabular}

Majority of group 1 patient's required mechanical ventilation and most of patients in group 2 could be managed on non-invasive ventilation. (Table 4)

\begin{tabular}{|c|c|c|c|c|c|c|c|}
\hline $\begin{array}{c}\text { Mode of } \\
\text { Ventilation }\end{array}$ & $\begin{array}{c}\text { Group 1 } \\
(\mathbf{n = 3 8})\end{array}$ & $\mathbf{\%}$ & $\begin{array}{c}\text { Group 2 } \\
(\mathbf{n = 4 9 )}\end{array}$ & $\mathbf{\%}$ & $\begin{array}{c}\text { Group 3 } \\
(\mathbf{n = 6 8})\end{array}$ & \% & $\begin{array}{c}\text { p- } \\
\text { Value }\end{array}$ \\
\hline $\mathrm{O}_{2}$ & 4 & 10.5 & 10 & 20.4 & 37 & 54.4 & $<0.001$ \\
\hline NIV & 8 & 21.1 & 22 & 44.9 & 21 & 30.9 & \\
\hline Ventilator & 26 & 68.4 & 17 & 34.7 & 10 & 14.7 & \\
\hline \multicolumn{7}{|c|}{ Table 4 } \\
\hline
\end{tabular}

A wide range of complications were observed in our study.

Cardiovascular complications were seen in $18.7 \%$ of the patients (29/155). The various cardiovascular complications observed in these patients were STEMI, NSTEMI, Myocarditis and Atrial fibrillation.

Renal complications, Acute Kidney Injury, was seen in $36.8 \%(57 / 155)$ of patients.

Neurological complications like Critical illness neuropathy, Dysautonomia, infarcts (Pontine, multicerebral), polyneuropathy, intracerebral haemorrhage were also observed in $5.2 \%(8 / 155)$ of our patients.

The survival rate was $63.9 \%(99 / 155)$.

Amongst the patients who died, (56/155; 36.1\%), 68.4\% belonged to group 1, $36.7 \%$ belonged to group 2 and $17.6 \%$ in group 3.

Mortality was highest in the H1N1 positive patients. Men had a higher mortality rate (52\%) than females. Duration of illness, age and co morbidities did not affect the mortality.

Factors predicting the morbidity and severity of the disease was evidenced by the $\mathrm{P} / \mathrm{F}$ ratio of $<100$. Mortality of the patients with a $\mathrm{P} / \mathrm{F}$ ratio of $>200$ was significantly more than in patients with a $\mathrm{P} / \mathrm{F}$ ratio of $<200$. (Table 5 ). The mean $\mathrm{P} / \mathrm{F}$ ratio among the patients who died was $143.7 \%$. There was $100 \%$ mortality in patients with severe ARDS in group 1 . 


\begin{tabular}{|c|c|c|c|c|c|}
\hline $\mathbf{P a O}_{2} / \mathbf{F i O}_{2}$ & $\begin{array}{c}\text { Dead } \\
(\mathbf{n = 5 6 )}\end{array}$ & $\mathbf{\%}$ & $\begin{array}{c}\text { Alive } \\
\text { (n=99) }\end{array}$ & \% & $\begin{array}{c}\mathbf{p}- \\
\text { Value }\end{array}$ \\
\hline $0-100$ (severe) & 17 & 30.1 & 5 & 5.1 & $<0.001$ \\
\hline $100-200$ (Mod Severe) & 29 & 51.8 & 62 & 62.6 & \\
\hline $200-300$ & 7 & 12.5 & 21 & 21.2 & \\
\hline$>300$ & 3 & 5.4 & 11 & 11.1 & \\
\hline \multicolumn{7}{|c|}{ Table 5 } \\
\hline
\end{tabular}

\section{DISCUSSION}

Respiratory illness caused by seasonal influenza caused severe illness with significant morbidity and mortality. The patients who presented with flu like illness had a varied severity of clinical presentation and many complications.

All the patients admitted with Category C were analysed and were divided into 3 groups. Group 1 (Tested positive), group 2 (Tested negative), group 3 (Untested group). The number of females were more than males. Majority of the patients were in the middle age group (40-59 years). In a study conducted by Gurav et al,(8) the most affected age group was 20 to 39 years.

Fever cough and breathlessness were the most common presenting symptoms. In other similar studies conducted in India, fever was the most common presenting symptom. $(9,10)$

Even though majority of patients presented to us before 7 days of illness and despite starting treatment as soon as they presented, the severity of the disease was not altered. Most of the patients had moderate ARDS.

The various complications noticed in our study were Cardiovascular (STEMI, NSTEMI, Myocarditis, Atrial fibrillation), Renal (Acute Kidney Injury), Neurological (Critical illness neuropathy, Dysautonomia, infarcts (Pontine, multicerebral), polyneuropathy, intracerebral haemorrhage). other studies showed that the extra pulmonary complications leading to the high mortality of the patients. The extra pulmonary manifestations including the heart (myocarditis), and central nervous system (encephalitis, myelitis, meningitis, febrile and afebrile seizures, Guillain-Barré syndrome, cerebellar ataxia).(11,12)

\section{CONCLUSION}

Patients with suspected and proven H1N1 infection, had varied clinical presentation and a wide range of unusual complications. Severe ARDS with a Pa02/FiO2 ratio of $<100$ could be used as a predictor for mortality. However, despite early presentation, the severity of the disease was unaltered.

\section{REFERENCES}

[1] Fraser C, Donnelly CA, Cauchemez S, et al. Pandemic potential of a strain of influenza A (H1N1): early findings. Science 2009;324(5934):1557-61.

[2] Fox M. Swine flu death rate similar to seasonal flu. September 16, 2009. Accessed on 11 December 2009. http://www.reuters.com/article/idUSTRE58E6NZ200 90916.

[3] Wang TT, Palese P. Unraveling the mystery of swine influenza virus. Cell 2009;137(6):983-5.

[4] Collignon P. Take a deep breath Swine flu is not that bad. Australasian Emergency Nursing Journal 2009;12(3):71-2.

[5] McConnell J. Influenza in the Asia-Pacific. Lancet Infect Dis 2009;9(10):590-1.

[6] Cordova A, Hernandez M, Lopez-Gatell H, et al. Update: Novel influenza A (H1N1) virus infection, Mexico, March-May, 2009. Morbidity and Mortality Weekly Report 2009;58(21):585-9.

[7] Choudhry A, Singh S, Khare S, et al. Emergence of pandemic 2009 influenza A H1N1, India. Indian J Med Res 2012;135(4):534-7.

[8] Gurav YK, Pawar SD, Chadha MS, et al. Pandemic influenza A(H1N1) 2009 outbreak in a residential school at Panchgani, Maharashtra, India. Indian J Med Res 2010;132:67-71.

[9] Kaji M, Watanabe A, Aizawa H. Differences in clinical features between Influenza A H1N1, A H3N2 and B in adult patients. Respirology 2003;8(2):231-3.

[10] Broor S, Gupta S, Mohapatra S, et al. Emergence of 2009A/H1N1 cases in a tertiary care hospital in New Delhi, India. Influenza Other Respir Viruses 2011;5(6):e552-7.

[11] Studahl M. Influenza virus and CNS manifestations. J Clin Virol 2003;28(3):225-32.

[12] Ekstrand JJ. Neurologic complications of influenza. Semin Pediatr Neurol 2012;19(3):96-100. 